\title{
Evaluation of some lupine genotypes based on genotype by trait (GT) biplot analysis and study the effect of soaking and cooking treatments on some physical and chemical properties of seeds.
}

\author{
Nagat G. Abdallah', Hoda E. A. Ibrahim², and Hanan A. M. Ali ${ }^{3}$ \\ ${ }^{1}$ Department of Food legumes, Res, Field crops Res. Inst. A.R.C., Giza, Egypt. \\ ${ }^{2}$ Central Laboratory for Design \& Statistical Analysis Research, A.R.C., Giza, Egypt \\ ${ }^{3}$ Central Laboratory of Organic Agriculture, A.R.C., Giza, Egypt.
}

Received on: 11-9-2021

Accepted on: 30-9-2021

\begin{abstract}
This research was established at the Agricu ltural Research Station in Mallawi, Minia governorate during the agricultural seas ons of $201 \mathrm{~V} / 201^{\wedge}$, and $201 \wedge / 201^{`}$, to Evaluate twelve lupine genotypes using biplot method and the effect of soaking and cooking treatments on some phy sical and chemical properties of seeds. The highest seed weight per plant obtained in Family 9 and Belbais 9 which gave high number of pods / plant, high weight of 100 and seed yield ardab / fed than the check varieties Giza 1 and Giza 2, Seed yield was significantly and positively correlated with 100 seed weight, seed weight / plant. The results of GT biplot graphs were consistent with those of correlation matrix and means table studies, showing that GT biplot graphs are a successful and useful approach. There was a clear variation with respect to water absorption, hydration and swelling coefficients, total phenols, alkaloids, tannins, total and soluble protein contents among the 12 different lupine seeds genotypes. Als o, the effects of s oaking and cooking on the abovementioned properties were noticeable where the water absorption values were ranged from 10.07\% (Family 23) to 10.6\% (Mutant 37/3) after 1 hr and from 26.93 (Family 23) to 28.31\% (Family 9) after 24 hrs. It could be seen that both soaking and cooking processes caused a decrease in total phenols, alkaloids, tannins, total and soluble protein contents for all lupine genotypes seeds samples as compared to the raw ones.
\end{abstract}

KEYWORDS: Lupin, biplot, alkaloids, soaking, cooking, phenols, tannins, protein.

\section{INTRODUCTION}

Lupine (Lupinus albus L.) cultivation has been known in Egypt for more than 3000 years B.C. Lupine is cultivated in a wide range of different environments across Egypt, and it is considered one of the crops of nutritional and health importance for humans and animals, due to the fact that it contains 42 protein, 18 percent of oil and is rich in essential amino acids and fibers (Julier et al., 1995). the productivity of lupin is not enough to achieve selfsufficiency. To improve this crop, we need a wide range of germplasm collection in addition to the available genotype. Screened and selected genotypes and adaptability trails may be used as sources of new genes to improve the commercial varieties. This is particularly useful in designing and evaluating breeding programs.

Espinoza et al. (2000); El-Sayad et al. (2002) found significant differences in their studies among either introduced or landrace genotypes in yield, components and alkaloid content.

Lupine, like other legumes, has anti-nutritive compounds that make it difficult to eat. It is difficult to eat without processing due to the presence of alkaloids (particularly, quinolizidine alkaloids). Tannins, another anti-nutritional component present in raw seed, are another anti-nutritional component. However, it has limits in terms of long-term usage. (Gulewiczet al., 2014).

Soaking has been shown to be an efficient therapy for removing anti-nutritional elements, which may be removed with the soaking solution discarded, certain metabolic processes can occur during soaking, altering the concentration of specific chemicals. (Vidal-Valverde et al., 1992). In general, soaking decreased anti-nutritional factors and increased in-vitro protein digestibility in general, although the benefits differed depending on legume cultivars and soaking circumstances such as soaking solution type, soaking time, and temperature. (ElBaltegy, 1996).

By removing the anti-nutritional elements found in lupine seeds, lupine flour may be utilised to make a variety of goods. It may be used to pasta, crisps, bread, cookie, cake, morning cereal, and emulsified meat products to boost nutritional value, change the scent, and change the texture. Lupine seeds are eaten as a snack in the Middle East after being soaked in water, scalded, and dehulled. Pickles are also made from lupine seeds in certain European countries. (Erbas et al., 2005).

Furthermore, numerous processing methods and traditional treatments like as dehulling, soaking, 
boiling, fermentation, and germination have been described as being utilised to minimise antinutritional components, enhance digestibility, and nutritional quality of edible beans to varying degrees. (Mubarak, 2005). The use of Lupines in food process applications requires reduction of content of non-nutritional ingredients such as tannins, alkaloids and oligosaccharides, undesirable compounds that must be removed before consumption ( Jimenez, 2001).

Only using correlation coefficients to make breeding decisions may not always be successful since they only give one-dimensional information and ignore the intricate interrelationships between plant characteristics. (Kang, 1994).

The genotype $\mathrm{x}$ trait (GT) biplot allows for the presentation of genuine correlations between characteristics as well as the comprehension of linkages that aid in the identification of features that may be utilised in indirect grain yield selection (Yan and Rajcan, 2002; Yan and Tinker, 2005). Furthermore, GT biplot provides information on cultivars' production utility as well as information that aids in the detection of less important (redundant) characteristics.

Swelam (2012) and Yan, 2014 used GT biplot graph to visualize the relationships among genotypes, traits and among them. In this investigation GT biplot graph could be successfully used for multi-traits selection in lupin breeding programs. Despite the recent interest shown in GT biplot graph to interpret the two-way table of genotype and traits, it is rarely used in the yield trials in Egypt. Few references were found concerning this technique.

The objectives of this work were:

1- Studying the effect of processing treatments such as soaking and cooking on the levels of tannins and TPCs (Total phenolic compounds) in lupine seeds and selected genotypes grown as they are introduced.

2- To determine the way in which yield components related to each other.

3- To identify genotype and trait relationships using correlation coefficient to discuss whether GT biplot graph is possible to be a good alternative procedure for correlation coefficient.

\section{MATERIALS AND METHODS}

This research was established at the Agricultural Research Station in Mallawi, Minia governorate during the agricultural seasonsof $201 \mathrm{~V} /$ $201 \wedge$ and $201 \wedge / 201{ }^{9}$ to study the performance of twelve lupine genotypes, including two commercial cultivars (Giza 1 and Giza 2) selected lines and induced mutant lines as shown in Table (1). These genotypes were selected according to a previous study done by (El-Sayed et al., 2002). The experiment was designed using randomized complete block design with three replications. Each plot contained 3 rows $60 \mathrm{~cm}$ apart and 3.5 meters length $\left(3.5 \times 0.6 \times 3=6.3 \mathrm{~m}^{2}\right)$. Agricultural practices were applied as usual in lupine field. At harvest stage, random samples of five plants were chosen from each plot. Data on number of days from sowing to $50 \%$ flowering and $90 \%$ maturity were obtained in each plot. Also, seed yield was recorded at harvest from the plot area and converted to the unit of ardab/feddan.

Five individual plants were taken from each plot to collect data on the following characters:

1- Plant height $/ \mathrm{cm}$.

2- No. of branches/plant.

3- No. of pods/plant.

4- No. of seeds/plant.

5- 100 seed weight in $\mathrm{gm}$.

6- Seeds weight/plant gm.

Table 1. Cultivars and mutants used in the evaluation trial (Origin: Egypt).

\begin{tabular}{llll}
\hline No. & Genotype & No. & Genotype \\
\hline $\mathbf{1}$ & Giza1 & $\mathbf{7}$ & Mutant 33 \\
$\mathbf{2}$ & Giza 2 & $\mathbf{8}$ & Belbais 9 \\
$\mathbf{3}$ & Mutant 23 & $\mathbf{9}$ & Mutant $37 / 3$ \\
$\mathbf{4}$ & Family 9 & $\mathbf{1 0}$ & Family 10 \\
$\mathbf{5}$ & Mutant $35 / 3$ & $\mathbf{1 1}$ & Line 14 \\
$\mathbf{6}$ & Family 12 & $\mathbf{1 2}$ & Local 12 \\
\hline
\end{tabular}

2.1.Processing treatments: -

The seeds were hand sorted and stored in polyethylene bags at about $4^{\circ} \mathrm{C}$ until analysis and use. Chemicals used in this investigation were of analytical grade and purchased from Sigma and ElNasr pharmaceutical chemicals Co., Egypt.

All samples were cleaned manually to remove foreign matters, immature and damaged seeds. Samples were washed and cleaned with tap water before soaked at room temperature $\left(\sim 25^{\circ} \mathrm{C}\right)$.

Soaking: Lupine samples were soaked in tap water for 24 hours at room temperature $\left(25^{\circ} \mathrm{C}\right)$ in a ratio of 1:4 (w/v). The soaked seeds were rinsed with distilled water after being washed twice with tap water. (Kaur and Kapoor, 1990).

Cooking: The soaked seeds (24 hr in tap water) were cooked in beakers with a seed to water ratio of 1:4 (w/v). The water was allowed to boil before the addition of the seeds. The seeds were cooked for 40 min (Embaby, 2010).

Soaked and cooked samples were dried in an oven at $50^{\circ} \mathrm{C}$ to a constant weight then they were ground to pass through a $0.25 \mathrm{~mm}$ sieve then packed in an airtight polyethylene bags until analyzed.

Water absorption during soaking (Hydration) was determined using the method of weight gain 
until equilibrium conditions were attained (Turhan et al., 2002).

Hydration coefficient of lupine seeds: was determined according to (El-Refai et al., 1988) using the weight measurements of lupine seeds samples before and after soaking under specified conditions (as mentioned before) and expressed as the percentage increase in weight as follows:

Hydration coefficient $(\%)=$

$$
100 \times \frac{\text { Weight of lupine seeds after soaking }}{\text { Weight of lupine seeds befor soaking }}
$$

Swelling coefficient of lupine seeds: was determined according to (El-Refai et al., 1988) and were expressed as the increase in volume percentage using the following equation:

Swelling coefficient $(\%)=$

$$
100 \times \frac{\text { Volume of lupine after soaking }}{\text { Volume of lupine befor soaking }}
$$

\section{Determination of total phenolic compounds (TPCs): -}

Total phenolic concentration was measured using Folin-Ciocalteu reagent as described by Velioglu et al. (1998). A standard curve was prepared expressing the results as mg gallic acid equivalents (GAE)/100g dry weight sample.

\section{Determination of total alkaloids:}

lupin bean flour $(5 \mathrm{~g})$ dispersing it in $50 \mathrm{ml}$ of $10 \%$ acetic acid solution in ethanol yielded the alkaloid content. After a good shake, the mixture was allowed to sit for about 4 hours before being filtered. On a heated plate, the filtrate was reduced to a fourth of its original volume. To precipitate the alkaloids, concentrated ammonium hydroxide was applied drop by drop. The precipitate was filtered out using pre-weighed filter paper, which was then washed with a 1 percent ammonium hydroxide solution. The precipitate-containing filter paper was dried in a $60^{\circ} \mathrm{C}$ oven for 30 minutes, then transferred to desiccators to cool before being reweighed until a consistent weight was achieved. It was noted that the weight remained unchanged. The weight of the alkaloid was calculated as a percentage of the sample dry weight assessed using the weight difference of the filter paper. (Hebourne JB, 1989).

\section{Determination of tannins:}

The tannin content was determined using Price et al.modified's vanillin- $\mathrm{HCl}$ in methanol technique (1978). In a $100 \mathrm{~mL}$ conical flask, $0.2 \mathrm{~g}$ of the ground material was put. Ten millilitres of $1 \%$ methanolic $\mathrm{HCl}(\mathrm{v} / \mathrm{v})$ was added, mixed for 20 minutes, then centrifuged for 5 minutes at $2500 \mathrm{rpm}$. One millilitre of supernatant was pipetted into a test tube, followed by 5 millilitres of vanillin-methanol reagent. After 20 minutes of incubation at $30{ }^{\circ} \mathrm{C}$, the absorbance was measured using a colorimeter spectrophotometer at $500 \mathrm{~nm}$. The data were expressed as catechin equivalents using a standard curve.

\section{Determination of total and soluble protein:}

Total protein was measured according to A.O.A.C (2005). According to Lowry et al., soluble protein was assessed (1951).

The results were given in $\mathrm{mg}$ of bovine serum albumin (BSA) protein per gramme of material (dry weight basis).

\subsection{Statistical analysis:}

Analysis of variance of RCBD as outlined by Gomez and Gomez (1984) was conducted. Levene test (1960) was run prior to the combined analysis to test the homogeneity of individual error terms. Least significant difference (LSD) test was used to detect the signific ant differences among genotype means at 0.05 probability level.

Simple correlation coefficients between seed yield (as resultant variable) and its related characters (as casual variables) were studied using simple correlation coefficients between all pairs of traits as suggested by Steel et al. (1997).

GGE biplot may be applied to any two-way data set, including genotypes with multiple characteristics. The genotype by trait (GT) biplot, which is an adaptation of the GGE biplot to examine genotype by trait data, was used by Gabriel (1971) and Yan and Rajcan (2002). The biplot technique was created using the standardized values of the trait means because the characteristics were assessed in various units.

\section{RESULTS AND DISCUSSION}

Before operating combined analysis of variance, using Levene test (1960) proved the homogeneity of separate error variances for all studied characters.

Results in Table (2) exhibited thatthemean square of genotype was highly significant for all studied characters while the mean square of season was only significant for each of NO, seeds/plant, and seed yield. The season $\mathrm{x}$ genotype effect was only highly significant for each of No.

Seeds/plant,100seedweight, seed weight /plant and seed yield.The significant genotype $\times$ year interaction indicated that differences among genotypes were not stable from 1 year to another, and these interactions are unavoidable in agricultural investigations (Yan and Kang, 2003). When the interaction effect between genotype and season was 
Table 2. Mean squares (MS) of the studied characters using combined analysis of the 12 lupine genotypes across two seasons of 2017- 2018 and 2018-2019

\begin{tabular}{|c|c|c|c|c|c|c|c|c|c|c|}
\hline S.O.V & $\Rightarrow$ & 告 & 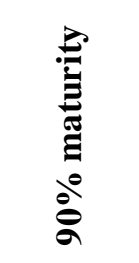 & 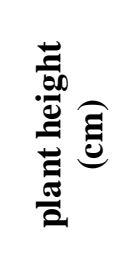 & 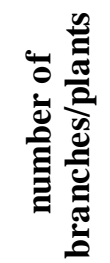 & 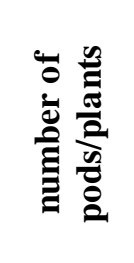 & 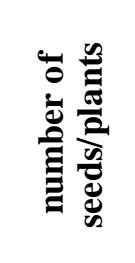 & 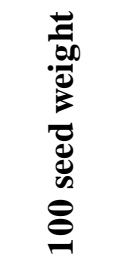 & ర্d & 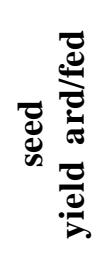 \\
\hline Seasons (S) & 1 & 0.50 & 0.22 & 1.39 & 0.0002 & 7.22 & $170.94 * *$ & 1.82 & 0.410 & $2.48 * *$ \\
\hline Rep/Season & 4 & 1.11 & 0.86 & 13.14 & 0.017 & 3.77 & 7.33 & 0.39 & 1.11 & 0.001 \\
\hline Genotypes (G) & 11 & $37.38^{* *}$ & $484.74 * *$ & $844.89^{* *}$ & $1.48 * *$ & $350.01 * *$ & $997.83^{* *}$ & $11.49 * *$ & $141.29 * *$ & $7.38 * *$ \\
\hline Genotypes $\times$ Season & 11 & 0.98 & 0.46 & 4.12 & 0.002 & 6.56 & $95.55 * *$ & $1.52 * *$ & $6.26 * *$ & $0.49 * *$ \\
\hline Residual & 44 & 0.64 & 0.88 & 8.99 & 0.01 & 2.29 & 13.17 & 0.54 & 1.52 & 0.09 \\
\hline Total & 71 & & & & & & & & & \\
\hline
\end{tabular}

$*, * *=$ Signific ant and highly significant at 0.05 and 0.01 levels of probability, respectively.

insignificant, it means that the lupine genotypes had similar behavior in the two seasons. Therefore, it is enough to present the combined averages across the two seasons without showing its seasonal averages. These results reflect the different genetic backgrounds of the studied genotypes.

\subsection{Agronomic characters:}

Results in Table (3) showed the mean values across the two seasons for yield and its components. It is noted that Mutant genotypes (Mutant 23, Mutant 33, Mutant 37/3 and Mutant 35/3) were the earliest genotypes in number of flowering and maturity days. The means of days to $50 \%$ flowering ranged from 75.667 for (Mutant 23) to 81.833 for Giza 1 where they matured at about 148.667 and 171.167 days respectively. The observed significant variation among the genotypes might partially reflect their different genetic backgrounds. The mutant genotypes showed that the lowest values of plant height ranged from $84.833 \mathrm{~cm}$ (Mutant 33) to $86.50 \mathrm{~cm}$ (Mutant 37/3), and number of branches per plant ranged from 3.233 (Mutant 23) to 4.833 (Family 9). Family 9 and Belbais 9 recorded the highest values of plant height $117.333 \mathrm{~cm}$ and $119.167 \mathrm{~cm}$ respectively. the highest number of branches/plants were also recorded by Family 9 and Belbais 9 in comparison with the other genotypes.

These results are in agreement with these obtained by Julier et al. (1995) and El-Sayed et al. (2002).

Table 3. Mean values of seed yield and its related characters over two seasons.

\begin{tabular}{|c|c|c|c|c|c|c|c|c|c|}
\hline 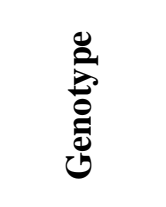 & 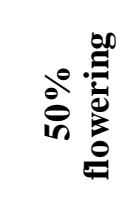 & ฉ゚ & 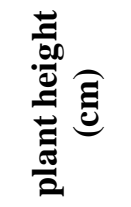 & 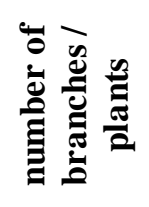 & 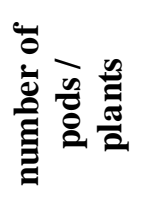 & 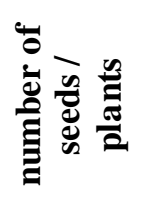 & 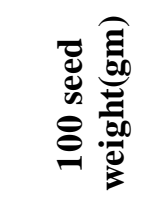 & 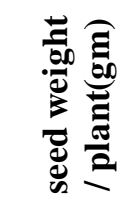 & 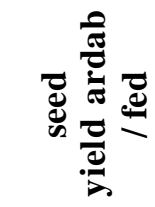 \\
\hline Giza1 & 81.833 & 171.167 & 95.833 & 3.922 & 27.883 & 103.363 & 31.392 & 32.527 & 5.363 \\
\hline Giza 2 & 81.333 & 171.167 & 95.833 & 4.000 & 24.250 & 91.067 & 31.720 & 28.958 & 4.842 \\
\hline Mutant 23 & 75.667 & 148.667 & 85.000 & 3.233 & 17.400 & 86.425 & 28.692 & 26.283 & 3.898 \\
\hline Family 9 & 80.333 & 165.500 & 117.333 & 4.833 & 37.867 & 112.173 & 32.613 & 36.445 & 6.698 \\
\hline $\begin{array}{l}\text { Mutant } \\
35 / 3\end{array}$ & 76.833 & 150.000 & 86.000 & 3.617 & 18.333 & 79.483 & 28.350 & 22.713 & 3.378 \\
\hline Family 12 & 81.167 & 164.833 & 97.833 & 3.917 & 28.400 & 94.297 & 29.792 & 28.067 & 5.589 \\
\hline Mutant 33 & 76.167 & 149.167 & 84.833 & 3.383 & 16.033 & 83.535 & 30.838 & 25.748 & 3.893 \\
\hline Belbais 9 & 80.333 & 165.667 & 119.167 & 4.817 & 38.767 & 117.265 & 32.545 & 37.903 & 6.820 \\
\hline $\begin{array}{l}\text { Mutant } \\
37 / 3\end{array}$ & 75.667 & 149.167 & 86.500 & 3.683 & 18.417 & 78.782 & 29.760 & 23.857 & 3.847 \\
\hline Family 10 & 81.333 & 165.333 & 104.000 & 4.167 & 28.333 & 103.808 & 30.117 & 31.275 & 4.945 \\
\hline Line 14 & 80.667 & 166.167 & 102.167 & 3.733 & 28.517 & 105.445 & 30.638 & 32.392 & 5.611 \\
\hline Local 12 & 81.333 & 166.167 & 104.833 & 4.217 & 31.000 & 104.557 & 31.632 & 33.710 & 5.216 \\
\hline Mean & 79.39 & 161.08 & 98.28 & 3.960 & 26.27 & 96.68 & 30.67 & 29.99 & 5.01 \\
\hline LSD 0.05 & 0.9319 & 1.089 & 3.488 & 0.1118 & 1.764 & 4.223 & 0.8584 & 1.435 & 0.3479 \\
\hline
\end{tabular}


B) Yield and yield components:

The means of yield and its components for 12 genotypes are shown in Table (3). The lowest seed weight / plant recorded by the mutant genotypes, they gave from 28.350 gm (Mutant 35/3) to $28.692 \mathrm{gm}$ (Mutant 23), alsotheygave the lowest number of pods / plant (16.033 to 18.42) and number of seed / plant (78.782 to 79.483). On the other hand, the highest 100 seed weightwere obtained in Family 9 and Belbais 9 which (32.613 and 32.545), and seed weight / plant (37.903 and 36.445) than the check variety Giza 1 and Giza 2 (31.392 gmand31.72 gm ).Other genotypes gave number of Pods / plant from 16.033 (Mutant 33) to 38.767 (Belbais 9), number of seeds / plant from 78.782 (Mutant 37/3) to 117.265 (Belbais 9) and100 seeds weight from 28.350 (Mutant 35/3) to 32.613(Family9). Family 9 and Belbais 9 recorded the highest estimates of seed yield ardab / fed $(6.698$ and 6.820) than that of check varieties Giza 1 (5.363 ardab) and Giza 2 (4.842 ardab), and other genotypes with an average (3.378 ardab). Similar trend was reported by El-Sayed et al. (2002).

\section{Correlation matrix}

Simple correlation coefficients among seed yield and its related attributes were estimated across two seasons as given in Table (4).
Results indicated that the relationship between seed yield ardab/feddan and the eight yield components were positive and highly significant. Data indicated that days to $50 \%$ flowering, $90 \%$ maturity, plant height, number of branches / plants, number of pods / plants, number of seeds / plants, 100 seed weight and seed weight/ plant had the greatest influence on seed yield ardab / fed with $\mathrm{r}$ values of $0.657^{* *}, 0.701^{* *}, 0.865^{* *}, 0.793^{* *}$, $0.894 * *, \quad 0.852 * *, \quad 0.589 * *$ and $0.845^{* *}$ respectively. It is suggested that seed yield of these lupine genotypes may be raised through selection for plants with more 100 seed weight, No.pods/plant and No.seeds /plant. These results confirm the finding of Riga et al. (2021) who stated that yield components exhibited various trends of associations among themselves. Highly significant and positive associations were observed among number of branches and days to $50 \%$ flowering and plant height and between plant height and number of branches /plant (correlation coefficients > 0.60) reporting that the tallest genotypes were lately flowering and increase number of branches /plant. The breeder should be aware about the nature of associations among yield components.

Table 4. Correlation coefficients between seed yield and its related attributes computed from 12 lupine genotypes evaluated across two seasons.

\begin{tabular}{llllllllll}
\hline Characters & $\mathbf{F}$ & $\mathbf{M}$ & $\mathbf{P h}$ & $\mathbf{N b}$ & $\mathbf{N p}$ & $\mathbf{N s}$ & $\mathbf{1 0 0} \mathbf{S W}$ & $\mathbf{S w} / \mathbf{p}$ & Sy/ard. \\
\hline $\mathbf{F}$ & 1 & & & & & & & & \\
$\mathbf{M}$ & $\cdot .924^{* *}$ & 1 & & & & & & & \\
$\mathbf{P h}$ & $\cdot .630^{* *}$ & $\cdot .666^{* *}$ & 1 & & & & & & \\
$\mathbf{N b}$ & $\cdot .606^{* *}$ & $\cdot .633^{* *}$ & $\cdot .904^{* *}$ & 1 & & & & & \\
$\mathbf{N p}$ & $\cdot .696^{* *}$ & $\cdot .732^{* *}$ & $\cdot .927^{* *}$ & $\cdot .905^{* *}$ & 1 & & & & \\
$\mathbf{N s}$ & $\cdot .667^{* *}$ & $\cdot .706^{* *}$ & $\cdot .850^{* *}$ & $\cdot .767^{* *}$ & $\cdot .885^{* *}$ & 1 & & & \\
$\mathbf{1 0 0 ~ S w}$ & $\cdot .488^{* *}$ & $\cdot .585^{* *}$ & $\cdot .609^{* *}$ & $\cdot .665^{* *}$ & $\cdot .620^{* *}$ & $\cdot .547^{* *}$ & 1 & & \\
Sy/p & $\cdot .656^{* *}$ & $\cdot .714^{* *}$ & $\cdot .870^{* *}$ & $\cdot .809^{* *}$ & $\cdot .896^{* *}$ & $\cdot .945^{* *}$ & $\cdot .713^{* *}$ & 1 & \\
Sy/ard. & $\cdot .657^{* *}$ & $\cdot .701^{* *}$ & $\cdot .865^{* *}$ & $\cdot .793^{* *}$ & $\cdot .894^{* *}$ & $\cdot .852^{* *}$ & $\cdot .589^{* *}$ & $\cdot .845^{* *}$ & 1 \\
\hline
\end{tabular}

(F) 50\% flowering, (M) 90\% maturity, (Ph) plant height (cm), (Nb) number of branches / plants. (Np) number of pods / plants, (Ns) number of seeds / plants, (100Sw) 100 seed weight, (Sy/p) seed yield / plant and (SY) seed yield ardab/ fed

\section{GT Biplot graph}

\section{1-Genotype comparison (polygon graph):}

Recently, the biplot graphs can be used to compare genotypes on the basis of multiple traits (seed yield and its related characters) and to identify genotypes that are particularly good in certain part or side in lupine breeding program (Yan and Rajcan, 2002 and Yan and Tinker, 2005).
The polygon view of a genotype by trait (GT) biplot graph is the best way to visualize the interaction patterns between genotypes and traits provided the biplot should explain a sufficient amount of the total variation.

The biplot graph (Fig1) presents the relationship among the aimed lupin genotypes using the seed yield (ardab/feddan) and its related attributes. The GT biplot of the lupin data's mean performance explained $97.5 \%$ of the entire variation 


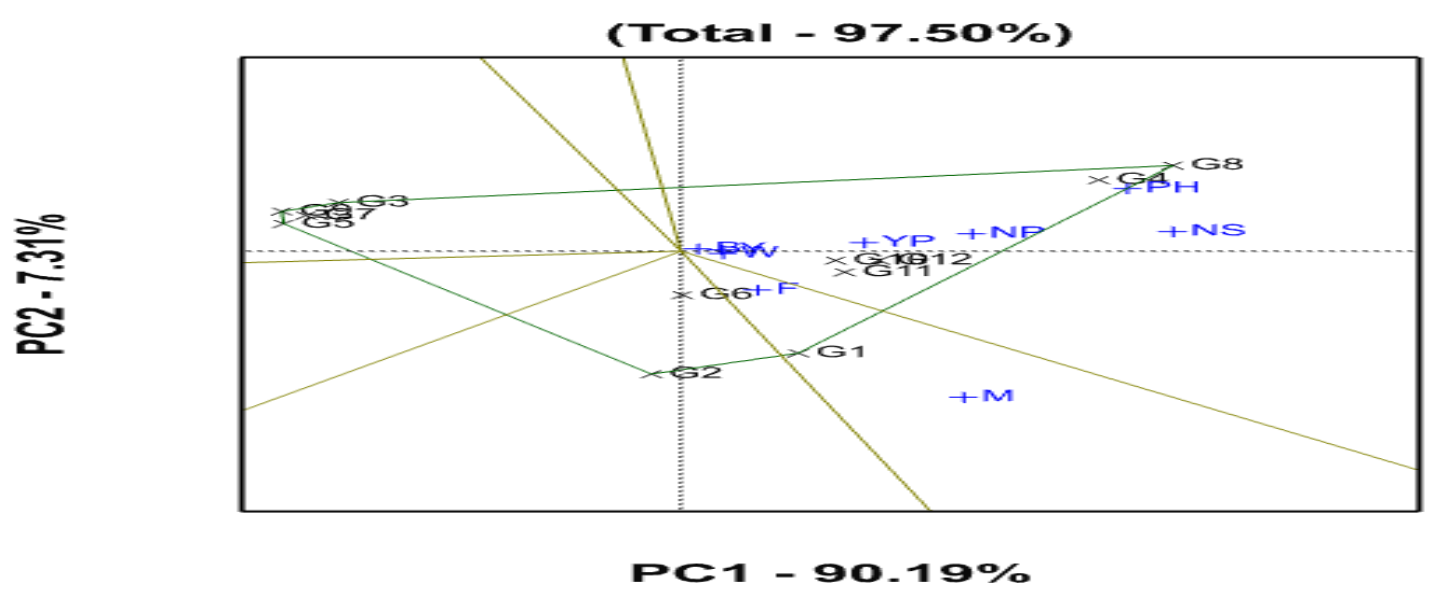

\section{Fig 1. Polygon view genotype by trait (GT) biplot showing which genotype had the highest values for which traits for 12 lupine genotypes.}

in the standardised data. The first and second principal components (PC1 and PC2), respectively, explained $90.19 \%$ and $7.31 \%$. The intricacy of the connections between genes and measured characteristics is reflected in this low proportion. According to Yan and Kang (2003), the first two PCs should reflect more than $97 \%$ of the total variance in order to achieve the GT biplot model's goodness of fit.

The perpendicular genotypes to the polygon sides facilitate comparison between neighboring vertex genotypes. It is obvious that genotype Belbais 9 (G8) and Family 9(G4) recorded high values of plant height $(\mathrm{PH})$ and number of seeds per plant (NS). Also, Giza1 (G1), Giza 2 (G2) reflected similar behavior tow ard the days to $50 \%$ flowering and days to $90 \%$ maturity.

It is noted that the points of these genotypes and traits placed into one sector and the angles among them were acute reflecting the positive associations among them.

Finally, the four genotypes Mutant 23 (G3), Mutant 35/3 (G5), Mutant 33(G7) and Mutant 37/3 (G9) were located far from most studied traits (obtuse angles) indicating to their poor performance toward these traits. The current results are in harmony with those obtained by Farrag et al. (2019).

Furthermore, the biplot approach is clearly an outstanding tool for visual data interpretation. The biplot methodology offers a few benefits over traditional data analysis approaches. The biplot's first benefit is its graphical data display, which substantially improves our capacity to grasp data patterns. The second benefit is that it is more interpretive and makes pair-wise genotype comparisons easier. The third benefit of this technique is that it makes it easier to identify potential genotypes or characteristic groupings. The fourth benefit is that it provides a full picture of how genotypes and characteristics interact. The current results are in harmony with those obtained by Swelam (2012); and Mahmoud et al, (2020).

\subsection{Effect of processing treatments on some physical and chemical properties:}

\subsubsection{Water absorption of lupine seeds during soaking:}

Understanding water absorption properties in legumes in general and lupines in particular during soaking is essential because it influences following operations and product quality (Turhan et al., 2002). As a result, characterising and optimising hydration processes as a function of time and temperature is required. (Abu-Ghannam and McKenna 1997 and Turhan et al., 2002).

The water absorption curves (water absorption capacity versus soaking time) of lupin seeds during soaking are shown in Fig $(r)$. From which, it could be observed that the water absorption rate was fast at the beginning and slow at the end of soaking process for all samples. It is evident from these curves that the values of water absorption increased with soaking time. They were ranged from 10.07 (Family 23) to $10.6 \%$ (Mutant 37/3) after $1 \mathrm{hr}$ and from 26.93 (Family 23) to $28.31 \%$ (Family 9) after $24 \mathrm{hrs}$. The difference between the water content at saturation and at a certain period, which is the driving force, determines the rate of water absorption. As hydration progresses, the water content rises, lowering the driving force and, as a result, the pace of absorption. When the seeds reach an equilibrium moisture content, the procedure comes to an end. (Resio et al., 2006). Similar observations were reported by Turhan et al. (2002); and Shafaei et al. (2016) for various agricultural materials. 


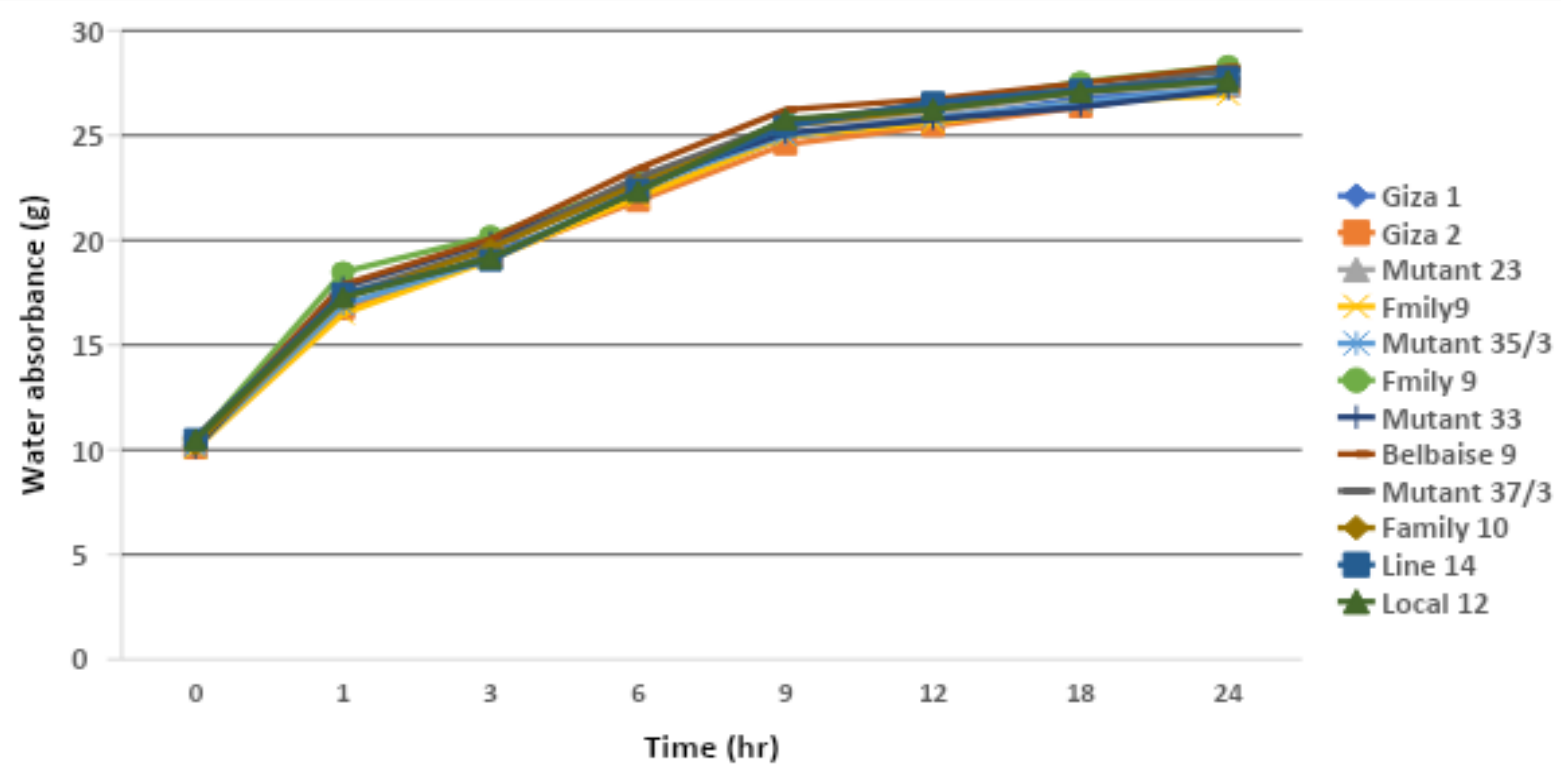

Fig 2. Effect of soaking and cooking on Water absorption in lupine seeds.

\subsection{2. hydration and swelling coefficients}

The differences in hydration and swelling coefficients of the studied lupine genotypes during soaking are presented in Table (5). The data indicate that hydration coefficient ranged from 263.31 to 275.62\% for Local 12 and Belbais 9, respectively. Also, the swelling coefficient varied between lupine genotypes where it ranged from 286.84 to 336.11 for
Family 10 and Belbais 9, respectively. Hydration and swelling coefficients which reflect the capacity to absorb water during soaking process was substantially affected by storage temperature. Both consumers and processors prefer beans that have high hydration and swelling coefficients as these produce greater quantity with better quality NasarAbbasa et al., 2008).

Table 5. Hydration and swelling coefficients of different lupine seeds genotypes.

\begin{tabular}{lcc}
\hline Genotypes & Hydration coefficient $\mathbf{( \% )}$ & Swelling coefficient $\mathbf{( \% )}$ \\
\hline Giza1 & 267.33 & 309.72 \\
Giza 2 & 271.22 & 328.13 \\
Mutant 23 & 266.33 & 327.58 \\
Family 9 & 267.37 & 288.73 \\
Mutant 35/3 & 268.51 & 301.39 \\
Family 12 & 271.41 & 317.32 \\
Mutant 33 & 270.10 & 302.78 \\
Belbais 9 & 275.62 & 336.11 \\
Mutant 37/3 & 265.04 & 305.55 \\
Family 10 & 269.97 & 286.84 \\
Line 14 & 264.50 & 308.83 \\
Local 12 & 263.31 & 305.72 \\
\hline
\end{tabular}

3.3. Effect of soaking and cooking processes on total phenol content of lupine seeds:

The obtained results for the phytochemicals content (total phenolic compounds (TPC), total tannins and total alkaloids) of raw, soaked and cooked lupine seeds are shown in Tables $(6,7$ and 8 ). From which, it could be seen that both soaking and cooking processes caused a decrease in the phytochemicals content for all lupine genotypes seeds samples as compared to the raw ones. From data in Table (6), it could be noticed that the TPC contents varied in different lupine genotypes from 551.27 to $726.37 \mathrm{mg} \mathrm{GAE} / 100 \mathrm{~g}$ in Local 12 and Belbais 9 in raw genotypes samples, respectively. However, all lupine genotypes seeds exhibited a noticeable reduction in TPC's levels by soaking and cooking methods, the decrease ranged from 3.05 to $24.42 \%$ for soaked lupine seeds in Family 12 and Belbais 9 genotypes, respectively. Meanwhile, the 
Table 6. Effect of soaking and cooking processes on total phenol content of different lupine seeds genotypes (dry weight basis).

\begin{tabular}{|c|c|c|c|}
\hline \multirow{2}{*}{ Genotypes } & \multicolumn{3}{|c|}{ Total phenol content mg GAE/100g } \\
\hline & Raw & soaked & Cooked \\
\hline Giza1 & 606.35 & 546.73 & 525.37 \\
\hline Giza 2 & 641.46 & 591.84 & 333.98 \\
\hline Mutant 23 & 577.49 & 497.48 & 452.77 \\
\hline Family 9 & 639.65 & 502.38 & 428.69 \\
\hline Mutant 35/3 & 658.06 & 593.19 & 452.42 \\
\hline Family 12 & 653.31 & 633.36 & 360.94 \\
\hline Mutant 33 & 564.60 & 544.38 & 400.93 \\
\hline Belbais 9 & 726.37 & 541.71 & 344.46 \\
\hline Mutant 37/3 & 628.33 & 548.64 & 474.24 \\
\hline Family 10 & 657.04 & 618.81 & 445.04 \\
\hline Line 14 & 597.68 & 538.09 & 438.25 \\
\hline Local 12 & 551.27 & 527.88 & 429.16 \\
\hline $\begin{array}{l}\text { decrease range } \\
\text { lupine seeds } \\
\text { respectively. } \\
\text { Vijayakumariet } \\
\text { phenolic comp } \\
\text { decrease in th } \\
\text { may be attrit } \\
\text { medium. Loss } \\
\text { result of: (a) } \\
\text { removal, or } \\
\text { (Barroga, 1985 }\end{array}$ & $\begin{array}{l}\text { o } 52.58 \% \text { for cooked } \\
\text { Belbais } 9 \text { genotypes, } \\
\text { re in agreement with } \\
\text { ho stated that since } \\
\text {-soluble in nature, the } \\
\text { nolics during soaking } \\
\text { ing into the soaking } \\
\text { content could be the } \\
\text { actability, (b) actual } \\
\text { chemical reactivity }\end{array}$ & \multirow{3}{*}{\multicolumn{2}{|c|}{$\begin{array}{l}\text { were eliminated (or decreased) by soaking raw seeds } \\
\text { in water before use. } \\
\text { Total alkaloids in lupine different genotypes } \\
\text { seeds (Table } 7 \text { ) ranged from } 0.96 \text { (Mutant } 35 / 3) \text { to } \\
1.60 \mathrm{mg} / 100 \mathrm{~g} \text { (Family 12) for raw lupine seeds. } \\
\text { These data revealed that, the highest decrease in } \\
\text { total alkaloids after soaking for } 24 \mathrm{hr} \text { was recorded } \\
\text { for Family } 9(50.35 \%) \text { followed by Giza } 1 \text { (50\%), } \\
\text { whereas Mutant } 35 / 3 \text { recorded the lowest decrease } \\
\text { values ( } 46.88 \%) \text {. However cooked lupine seeds } \\
\text { decreased total alkaloid in in lupine seeds varied } \\
\text { from } 64.29 \% \text { in Mutant } 23 \text { to } 69.93 \% \text { in Family } 9 . \\
\text { These findings were in line with those of Abishu and } \\
\text { Kefale ( } 2017) \text {, who found that soaking and cooking } \\
\text { processing techniques for lupine beans were } \\
\text { extremely effective in increasing nutritional quality } \\
\text { and lowering alkaloid content. }\end{array}$}} \\
\hline \multicolumn{2}{|c|}{$\begin{array}{l}\text { 3.4. Fffect of soaking and cooking processes } \\
\text { on total alkaloids of lupine seeds: }\end{array}$} & & \\
\hline $\begin{array}{l}\text { The genus } \\
\text { slightly poison } \\
\text { have a bitter }\end{array}$ & $\begin{array}{l}\text { und } 500 \text { species. The } \\
\text { loids found in plants } \\
\text { asumed raw, and are }\end{array}$ & & \\
\hline
\end{tabular}
employed as a defence mechanism by herbivorous animals (Hebourne, 1973). Traditionally, alkaloids

Table 7. Effect of soaking and cooking processes on total alkaloids of different lupine seeds genotypes (dry weight basis).

\begin{tabular}{llll}
\hline & \multicolumn{3}{c}{ Total alkaloid\% } \\
\cline { 2 - 4 } Genotypes & Raw & Soaked & Cooked \\
\hline Giza1 & 1.44 & 0.72 & 0.46 \\
Giza 2 & 1.40 & 0.73 & 0.44 \\
Mutant 23 & 0.98 & 0.50 & 0.35 \\
Family 9 & 1.43 & 0.71 & 0.43 \\
Mutant 35/3 & 0.96 & 0.51 & 0.31 \\
Family 12 & 1.60 & 0.82 & 0.51 \\
Mutant 33 & 1.19 & 0.61 & 0.36 \\
Belbais 9 & 1.53 & 0.81 & 0.50 \\
Mutant 37/3 & 0.99 & 0.50 & 0.30 \\
Family 10 & 1.58 & 0.82 & 0.49 \\
Line 14 & 1.53 & 0.80 & 0.51 \\
Local 12 & 1.54 & 0.78 & 0.47 \\
\hline
\end{tabular}




\subsection{Effect of soaking and cooking processes on tannin content of lupine seeds:}

Tannins are known to block digestive enzymes, lowering the digestibility of most nutrients, particularly protein and carbs. (Reddy and Pierson, 1994). As showed in Table (8) Belbais 9 lupine genotype seeds recorded the higher tannins content (365.79mg/100g) while, Mutant 33 lupine genotype seeds recorded the lowest tannins content (278.01 $\mathrm{mg} / 100 \mathrm{~g}$ ). Total tannins decreased by soaking seeds for $24 \mathrm{hr}$. Family 12 lupine genotypes seeds recoded highest reduction $31.09 \%$ while Mutant 33 seeds recorded the lowest reduction $3.63 \%$. These results are in agreement with Babiker and El Tinay (1993) who studied the effect of soaking processes on tannin content of faba bean seeds; they concluded that soaking of seeds in distill water for different times and temperatures significantly reduced tannin content.

Cooking lupine genotypes seeds caused further decrease in total tannins, the decrease ranged from 29.31\% in Mutant 35/3 seeds to 55.89\% in Belbais 9 seeds.

This reduction could be due to the removal of soluble tannins during soaking process, which were eliminated with the discarded soaking solution. It could also be due to the thermal degradation of these compounds and changes in their chemical reactivity or formation of insoluble complexes which may occur during cooking process. Similar observations were reported by Mubarak (2005) and Mehanniet al. (2017) for various agricultural materials.

Table 8. Effect of soaking and cooking processes on tannin content of different lupine seeds genotypes (dry weight basis).

\begin{tabular}{llll}
\hline & \multicolumn{3}{c}{ Total tannins mg/100g } \\
\cline { 2 - 4 } Genotypes & Raw & Soaked & Cooked \\
\hline Giza1 & 300.90 & 267.34 & 174.86 \\
Giza 2 & 318.81 & 297.41 & 218.42 \\
Mutant 23 & 285.41 & 244.01 & 153.61 \\
Family 9 & 314.69 & 247.71 & 163.21 \\
Mutant 35/3 & 308.03 & 291.62 & 217.75 \\
Family 12 & 323.42 & 222.86 & 166.76 \\
Mutant 33 & 278.01 & 267.91 & 193.37 \\
Belbais 9 & 365.79 & 265.46 & 161.36 \\
Mutant 37/3 & 311.12 & 215.02 & 165.42 \\
Family 10 & 329.35 & 271.32 & 214.04 \\
Line 14 & 355.98 & 297.54 & 211.74 \\
Local 12 & 350.29 & 274.79 & 208.43 \\
\hline
\end{tabular}

3.6. Effect of soaking and cooking processes on total and soluble protein content of lupine seeds:

The obtained results for total and soluble protein content of raw, soaked and cooked lupine seeds are shown in Table (9). From which, it could be seen that both soaking and cooking processes caused a decrease in both total and soluble protein content for all lupine genotypes seeds samples as compared to the raw ones. Data in Table (9) indicated that total protein contents varied in different lupine genotypes from 26.62 to $41.99 \%$ in Local 12 and Belbais 9 raw genotypes samples, respectively. While the soluble protein content varied in different lupine genotypes from 0.95 to $1.29 \mathrm{mg} / \mathrm{g}$ in Giza 2 and Family12, respectively. However, all lupine genotypes seeds showed a reduction in total and soluble protein content by soaking and cooking methods, the decrease in total protein content in soaked and cooked samples ranged from 3.53 to $18.22 \%$ and from 5.93 to $19.17 \%$, respectively in Giza 2 and Family 10 genotypes, respectively. Meanwhile, the decrease in soluble protein content ranged from 4.76 to 15.97 $\mathrm{mg} / \mathrm{g}$ for soaked lupine seeds in Mutant 37/3 and Mutant 23 genotypes, respectively. While it ranged from 8.73 to $22.11 \mathrm{mg} / \mathrm{g}$ for cooked seeds in Mutant $37 / 3$ and Giza 2 genotypes, respectively. These findings are consistent with Agume et al. (2017), who suggested that this might be due to soluble protein leaking into the soaking water. Also, according to Nithya (2007), the loss of crude protein in heat-treated grains might be attributable to protein denaturation and degradation.

The leaching out of low molecular weight chemicals into the soaking water might explain the reduction in crude protein concentration in comparison to soaking treatments. 
Table 9. Effect of soaking and cooking processes on total and soluble protein content of different lupine seeds genotypes (dry weight basis).

\begin{tabular}{lcccccc}
\hline & \multicolumn{2}{c}{ Raw } & \multicolumn{2}{c}{ Soaked } & \multicolumn{2}{c}{ Cooked } \\
\cline { 2 - 7 } Genotypes & $\begin{array}{c}\text { Total } \\
\text { protein } \\
(\boldsymbol{\%})\end{array}$ & $\begin{array}{c}\text { Soluble } \\
\text { protein(mg/g) }\end{array}$ & $\begin{array}{c}\text { Total } \\
\text { protein } \\
(\boldsymbol{\%})\end{array}$ & $\begin{array}{c}\text { Soluble } \\
\text { protein } \\
(\mathbf{m g} / \mathbf{g})\end{array}$ & $\begin{array}{c}\text { Total } \\
\text { protein } \\
(\boldsymbol{\%})\end{array}$ & $\begin{array}{c}\text { Soluble } \\
\text { protein } \\
(\mathbf{m g} / \mathbf{g})\end{array}$ \\
\hline Giza1 & 33.93 & 1.05 & 30.17 & 0.96 & 29.90 & 0.87 \\
Giza 2 & 34.04 & 0.95 & 32.84 & 0.82 & 31.00 & 0.74 \\
Mutant 23 & 37.79 & 1.19 & 34.00 & 1.00 & 33.76 & 0.95 \\
Family 9 & 30.25 & 1.20 & 26.47 & 1.11 & 25.89 & 1.09 \\
Mutant 35/3 & 41.97 & 1.01 & 38.52 & 0.95 & 37.78 & 0.90 \\
Family 12 & 26.80 & 1.29 & 22.98 & 1.19 & 21.81 & 1.10 \\
Mutant 33 & 30.49 & 0.97 & 26.59 & 0.89 & 25.00 & 0.82 \\
Belbais 9 & 41.99 & 1.02 & 38.00 & 0.94 & 36.90 & 0.90 \\
Mutant 37/3 & 34.21 & 1.26 & 30.42 & 1.20 & 28.89 & 1.15 \\
Family 10 & 41.93 & 1.09 & 34.29 & 1.00 & 33.89 & 0.93 \\
Line 14 & 38.14 & 1.00 & 34.31 & 0.90 & 33.14 & 0.84 \\
Local 12 & 26.62 & 1.11 & 23.84 & 1.02 & 22.99 & 0.94 \\
\hline
\end{tabular}

\section{Conclusions}

It can be concluded from the results

Family 9 and Belbais 9 recorded the highest estimates of seed yield (ardab / fed) than that of check varieties i.e., Giza 1 and Giza 2, and other genotypes. the relationship between seed yield and the eight yield components were positive and highly signific ant.GT biplot graph is preferred because it is easy to interpret and gave more information. soaking and cooking processes caused a decrease in total phenols, alkaloids, tannins, total and soluble protein contents for all lupine genotypes seeds samples as compared to the raw ones.

\section{REFERENCE}

Abeshu Y, Kefale B (2017). Effect of some traditional processing methods on nutritional composition and alkaloid content of lupine bean. Journal of Natural Sciences Research, 7(21): 17-21.

Abu-Ghannam N, McKenna B (1997). Hydration kinetics of red kidney beans (Phaseolus vulgaris L.). J. Food Sci., 62 (3): 520-523.

Algan N, Aygün H (2001). Correlation between yield and yield components in some winter rape genotypes (In Turkish). The journal of Ege University, Agricultural Faculty, 38(1): 9-15.

Agume ASN, Njintang NY, Mbofung CMF (2017). Effect of soaking and roasting on the physicochemical and pasting properties of soybean flour. Foods, 6(2):12.

AOAC (2005). Official methods of analysis . $17^{\text {th }}$ edn. Association of Analysis Chemists. Washington DC.

Babiker EE, El-Tinay AH (1993). Effect of reconstitution and $\mathrm{Na} 2 \mathrm{Co} 3$ on Tannin content and in vitro protein digestibility of faba bean cultivars. Plant Food for Human Nutrition, 44:119-130
Barroga FC, Laurena CA, Mendoza TE (1985). Effect of condensed tannins on the in vitro protein digestibility of mungbean (Vigna radiata (L.) Wilczek). J. Agric Food Chem., 33:1157-1160.

El-Baltegy A (1996). Effect of home traditional methods on quality aspect of some legumes. M.Sc. Thesis, Faculty of Agriculture, Minofiya University, Shibin El-Kom, Egypt.

El-Refai AA, Harras HM, El-Nemr KM, Noaman MA (1988). Chemical and technological studies on faba bean seeds. I. Effect of storage on some physical and chemical properties. Food Chem., 29: 27-39.

El-Sayad ZS, Ashmawy F, Attia SM, EL-Lithy RE(2002). The relative important of some characters to seed yield of white lupin as affected by planting dates and plant densities. J. Agric. Sci., Mansoura univ., 27(1):71-83.

Embaby HE (2010). Effect of soaking, dehulling, and cooking methods on certain antinutrients and in vitro protein digestibility of bitter and Sweet Lupin Seeds. Food Sci. Biotechnol,19 (4): 10551062 .

Erbas M, Certel M, Uslu MK (2005). Some chemical properties of white lupin seeds (Lupinus albus L.). Food Chem., 89:341-345.

Espinoza LC, Huyghe C, Papineau J (2000). Genetic variation for pod wall proportion in lupines albus. Plant Br.,(119):421-425.

Farrag ME, Soliman SS, Amer IM, Heake RM, Hassanin AA (2019). Analysis of genetic diversity among a population of canola genotypes as reveled by issr-pcr and their associations to seed yield and oil content .Annals of Agric. Sci., Moshtohor, Vol. 57 (2), $425-434$.

Gabriel KR (1971). The biplot graphic display of matrices with application Genome, 53 (11): 9921001. 
Gomez KA, Gomez AA (1984). Statistical Procedures for Agricultural Research. $2^{\text {nd }}$ Ed., John Wiley and Sons, New York, USA.

Gulewicz P, Martinez-Villaluenga $\quad$, Kasprowicz-Potocka M, Frias J (2014). Nonnutritive compounds in Fabaceae family seeds and the improvement of their nutritional quality by traditional processing - a Review. Pol. J. Food Nutr. Sci., 64(2):75-89.

Harborne JB (1973). Methods of plant analysis. In: Phytochemical Methods, Chamman and Hall, London.

Harbourne JB (1989). Biosynthesis and functions of anti-nutritional factors in plants. Aspects Appl. Biol., 19:21-28.

Jimenez-Martinez C (2001). Effect of aqueous and alkaline thermal treatments on chemical composition and oligosaccharide, alkaloid and tannin contents of Lupinus campestris seeds. J. Sci. Food Agric., $81: 421-428$.

Jimenez MC, Hernandez-Sanchez H, DavilaOrtiz G (2003). Lupines: An Alternative for Debittering and Utilization in Foods. Food Sci. Food Biotech., 11: 233-251.

Julier B, Huyghe C, Papineau J, Bilot C, Deroo C (1995). Genetic and environmental variation in architecture and yield components in determinate white lupin (L. albus) .Euphytica, 81(2):171-179.

Kang MS (1994). Applied Quantitative Genetics. Kang publ. Baton Rouge, LA, USA

Kaur D, Kapoor A (1990). Starch and protein digestibility of rice bean (Vigna umbellata)-effects of domestic processing and cooking methods. Food Chem., 38:263-272.

Levene H (1960). Robust tests for equality of variances. In Ingram Olkin, Harold Hotelling, Italia, Stanford, Univ. Press, PP. 278- 292.

Lowry OH, Rosenbrough NJ, Farr AL, Randall RJ (1951).Protein measurement with the Folin Phenol Reagent. J.Biol. Chem., 193:265-275.

Mahmoud MWSh, Eman MA Hussein, Ashour KR (2020). Sequential path analysis for determining the interrelationships between yield and its components in peanut. Egypt. J. Agron., 42(1):7991.

Mehanni AE, Sorour MA, Abd El-Galel H, Ahmed WK (2017). Polyphenols, tannins and phytate contents in some egyptian legumes as affected by soaking and germination processes. BAOJ Food Sci. Tec., 1 (1): 1-7.

Mubarak AE (2005). Nutritional composition and antinutritional factors of mung bean seeds (Phaseolus aureus) as affected by some home traditional processes. Food Chemistry, 89:489-495. Nasar-Abbasa SM, Plummera JA, Siddique KHM, White P, Harris D, Dods $K$ (2008). Cooking quality of faba bean after storage at high temperature and the role of lignins and other phenolics in bean hardening. LWT- Food Science and Technology, 41: 1260-1267.

Nithya KS, Ramachandramurty B, Krishnamoorthy VV (2007). Effect of processing methods on nutritional and anti-nutritional qualities of Hybrid (COHCU-8) and traditional (CO7) Pearl Millet varieties of India. J. Biol. Sci., 7(4):643-647.

Price ML, Scoyoc SV, Butler LG (1978). A critical evaluation of the vanillin reaction as an assay for tannin in sorghum grain. J. Agric. Food Chem., 26:1214-1218.

Reddy NR, Pierson MD (1994). Reduction in antinutritional and toxic components in plant foods by fermentation. Food Research International, 27:281-290.

Resio AC, Aquerre RJ, Suarez C (2006). Hydration kinetics of amaranth grain. J. Food Eng., 72, 247-253.

Riga FT, Retta KS, Derseh MB (2021). Yield and nutritional quality of sweet Lupine (lupinusangustifolius) grown in midaltitudes of lemodistrict, Hadiya Zone, Southern Ethiopia International Journal of Agronomy, Article ID 6674452, $10 \quad$ pages https://doi.org/10.1155/2021/6674452.

Shafaei SM, Masoumi AA, Roshan H (2016). Analysis of water absorption of bean and chickpea during soaking using Peleg model. Journal of the Saudi Society of Agricultural Sciences, 15:35- 144. Steel RGD, Torrie JH, Dickey DA (1997). Principles and Procedures of Statistics: A Biometrical Approach. $3^{\text {rd }}$ ed. Mc Graw Hill Book Co. New York.

Swelam AA (2012). Phenotypic stability, biplot analysis and interrelationship among agronomic characters for some bread wheat genotypes. Egypt.

J. Plant Breed., 16(4):147-165.

Turhan M, Sayar S, Gunasekaran S (2002). Application of Peleg model to study water absorption in chickpea during soaking. J. Food Eng., 53:153-159.

Vidal-Valverde C, Frias J, Vulverde S (1992). Effect of processing on anti-nutritional factors of lentils. J. Food Prot., 55:301- 306.

Vijayakumari K, Pugalenthi M, Vadivel V (2007). Effect of soaking and hydrothermal processing methods on the levels of antinutrients and in vitro protein digestibility of Bauhinia purpurea L. seeds. Food Chemistry, 103:968-975.

Velioglu Y, Mazza G, Gao L, Oomah B (1998). Antioxidant Activity and Total Phenolics in Selected Fruits, Vegetables, and Grain Products. J. Agric. Food Chem., 46(10):4113-4117.

Yan W (2014). Genotype-by-trait data analysis and decision-making. Chapter 9, In: Yan W (ed.) Crop 
variety trials: data management and analysis, 1 st ed. John Wiley and Sons, INC., New York. pp 163-186. Yan W, Rajcan IR (2002). Biplot analysis of test sites and trait relations of soybean in Ontario. Can. J. Plant Sci., 42:11-20.
Yan W, Kang MS (2003). GGE-biplot analysis: a graphical tool for breeders. Geneticists and Agronomists, CRD Press, Boca Raton.

Yan W, Tinker NA (2005). An integrated system of biplot analysis for displaying, interpreting, and exploring genotype-by-environment interactions. Crop Sci., 45:1004-1016.

\section{الملخص العريي}

\section{تقييم بعض التراكيب الوراثية لمحصول الترمس باستخدام تحليل المحاور الثنائية( للتراكيب الوراثية} والصفات) ودراسة تأثير معاملات النقع والطهى على بعض الخصائص الطبيعية والكيميائية للبذور

$$
\begin{aligned}
& \text { نجاة جابر عبد الله' و هدي السيد العربي ابراهيمَّ و حنان أبو الفتوح محمد على } \\
& \text { 'قسم بحوث المحاصيل البقولية - معهد بحوث المحاصيل الحقلية - مركز البحوث الزراعية- الجيزة } \\
& \text { rالمعمل المركزي لبحوث التصميم و التحليل الإحصائي - مركز البحوث الزراعية - الجيزة } \\
& \text { rالمعمل المركزي للزراعة العضوية - مركز البحوث الزراعية - الجيزة }
\end{aligned}
$$

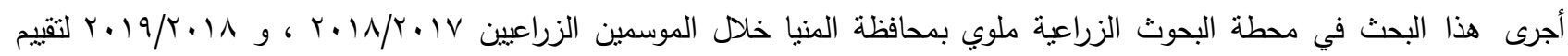
بعض التراكيب الوراثية للترمس باستخدام الأشكال البيانية لطريقةالمحاور الثنائية وتأثير معاملات النقع والطبخ على بعض الخواص الفيزيائية

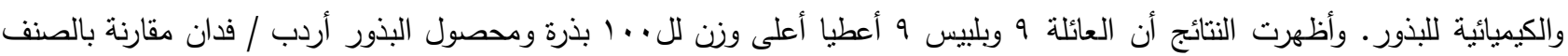
المقارن جيزة ا وجيزة Y ، وكان محصول البذور أردب / فدان. يرنبط ارنباطًا معنويا وإيجابيًا مع وزن · · (بذرة ، محصول البذور / نبات توافقت النتائج التي تم الحصول عليها بواسطة الرسوم الييانية biplot GT مع تلك التي تم الحصول عليها من خلال مصفوفة الارتباط وجدول المتوسطات الذي يشنير إلى أن الرسم اليياني GT biplot يعنبر أسلوبًا ناجحًا وفعالًا بجانب هذه التحليلات أو بدلاً منها. كما كان هناك تباين واضح فيما يتعلق بامتصاص الماء ومعاملات الترطيب والانتفاخ ، إجمالي الفينولات ، القلويات ، التانين ، محتوى البروتين الكلي والقابل للذوبان بين rا تركييا وراثيًا مختلفًا من بذور الترمس. كما أن تأثنير النقع والطهي على الخصائص المذكورة أعلاه كان ملحوظًا حيث

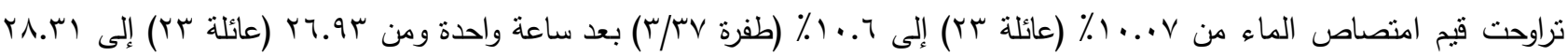

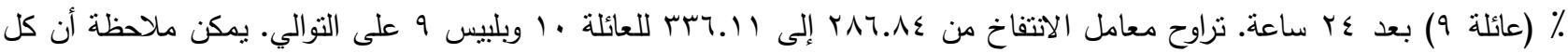
من عمليات النقع والطهي تسبيت في انخفاض إجمالي الفينولات والقلويدات والتانبن ومحتويات البروتين الكلي والقابل للذوبان لجميع عينات بذور الترمس مقارنةً بالخام. 